\title{
NK and NKT cell dynamics after rituximab therapy for systemic lupus erythematosus and rheumatoid arthritis
}

\author{
Eliana A. G. Reis · Daniel A. Athanazio · Isabella Lima • Natália Oliveira e Silva • \\ Jorge Clarencio S. Andrade · Ronden N. Jesus • Lúcio M. Barbosa • \\ Mitermayer G. Reis $\cdot$ Mittermayer B. Santiago
}

Received: 27 July 2008 / Accepted: 7 September 2008 / Published online: 28 September 2008

(C) Springer-Verlag 2008

\begin{abstract}
Biomarkers of clinical response to rituximab (RTX) therapy and early predictors of outcome are still under investigation. We report a flow cytometric immunophenotyping analysis from peripheral blood leukocyte subpopulations of two patients with systemic lupus erythematosus (SLE) associated thrombocytopenia and one patient with rheumatoid arthritis (RA), before and after 6 weeks of treatment with RTX. Our results show a reduced population of $\mathrm{CD}_{1} 9^{+}$expressing cells (B cells) after RTX treatment in all three patients. Increased frequency of peripheral regulatory $\mathrm{CD} 4^{+} \mathrm{CD} 25^{\text {high }} \mathrm{T}$ cell subset and the $\mathrm{CD}^{-} \mathrm{CD} 16^{-} \mathrm{CD} 56^{\text {bright }} \mathrm{NK}$ cell subset after RTX therapy were also observed in all patients, the latter being more pronounced in the SLE patient with sustained clinical response. In addition, an increased population of NKT cell subsets was observed in the patients with clinical response. This is the first evaluation of NK and NKT cells as biomarkers of clinical response after rituximab therapy in rheumatic diseases.
\end{abstract}

E. A. G. Reis - D. A. Athanazio - J. C. S. Andrade - R. N. Jesus ·

L. M. Barbosa - M. G. Reis

Oswaldo Cruz Foundation, Salvador, Brazil

D. A. Athanazio - R. N. Jesus · M. G. Reis

Federal University of Bahia, Salvador, Brazil

I. Lima $\cdot$ M. B. Santiago ( $\square)$

Serviço de Reumatologia do Hospital Santa Izabel,

Praça Almeida Couto 500, Nazaré, Salvador,

Bahia CEP 40050-001, Brazil

e-mail: mitter@svn.com.br

N. O. e Silva $\cdot$ M. G. Reis · M. B. Santiago

Escola Bahiana de Medicina e Saúde Pública (Medical School),

Salvador, Brazil
Keywords Systemic lupus erythematosus .

Rheumatoid arthritis · Natural killer cells · Rituximab ·

Leukocytes

\section{Introduction}

Rituximab (RTX) is a monoclonal antibody against CD20 that emerges as an important option of biologic therapy for autoimmune diseases. It was first approved for the treatment of non-Hodgkin lymphomas in 1997 by the Food and Drug Administration, United States. Its application in rheumatology was first evaluated for rheumatoid arthritis (RA) and later for other conditions including systemic lupus erythematosus (SLE), with promising results [1]. CD20 is a non-glycosylated surface membrane phosphoprotein restrictedly expressed in B lymphocytes before plasma cell differentiation. Importantly, since plasma cells are not a target for anti-CD20 antibodies, some autoantibodies may persist in serum even after depletion of B cells and clinical improvement of rheumatic diseases [1,2].

The exact mechanism of how RTX influences the immune responses in autoimmune disorders leading to clinical remission is not known yet. B cell depletion and inhibition of antibody production are unlikely to explain all its therapeutic effects. RA has a poorly understood pathogenesis but the widely accepted view identifies rheumatoid factor as an epiphenomenon rather than an autoantibody directly implicated in disease [1]. Furthermore, there is not a clear association between clinical improvement after RTX therapy and B cell depletion, for either RA or SLE patients, or lowering titers of anti-double stranded DNA antibodies (dsDNA), for SLE patients [1-5] and, thus, research in RTX therapy in autoimmune diseases includes seeking new biomarkers that may predict or measure therapeutic response [6]. 
B lymphocytes are not viewed anymore as merely antibody producing cells. They may act as antigen presenting cells (APCs) being the major source of T lymphocyte activation in some models. Moreover, B lymphocytes may produce high amounts of cytokines with immunomodulatory effects $[1,2,7]$. Decreased $\mathrm{T}$ helper cell activation after RTX treatment has been suggested on the basis of lower frequency of costimulatory $\mathrm{T}$ cell molecule CD40L positive cells that has been associated with partial and complete remission in patients with lupus nephritis [3, 8]. Interestingly, flow cytometry analysis of peripheral blood leukocytes after RTX therapy have shown additional effects on other cell types other than B lymphocytes [2, 3, 7]. After RTX therapy, macrophages produce lower amounts of $\mathrm{TNF} \alpha$ and exhibit increased expression of CD68, thus developing an APC phenotype as compensatory mechanism for the depletion of APC functioning B cells in RA [9]. Natural killer (NK) and NKT cells are recognized by their cytotoxic and regulatory effects, implicated in prevention of autoimmunity $[10,11]$. For example, NKT cell frequency in peripheral blood is lower in patients with SLE when compared to healthy subjects [12] and decreased values of NKT cell counts are associated with higher levels of anti-dsDNA [13]. $\mathrm{T} \mathrm{CD} 4^{+} \mathrm{CD} 25^{\text {high }}$ cells are important natural modulators of self-antigen $\mathrm{T}$ cell mediated responses [14]. While such natural regulatory $\mathrm{T}$ cells are reduced in patients with SLE $[15,16]$, inducible $\mathrm{CD} 4^{+} \mathrm{IL} 10^{+}$regulatory $\mathrm{T}$ cell count increases in SLE patients probably as result of compensatory mechanism [15].

The aim of this study was to explore the relationship of the peripheral blood regulatory NK, NKT cell subsets and $\mathrm{CD} 4{ }^{+} \mathrm{CD} 25^{\text {high }} \mathrm{T}$ cells with clinical response after RTX therapy.

\section{Patients}

\section{Case 1 (SLE)}

A 21-year-old female patient had 4-year past history of SLE presenting during evolution: malar rash, photosensitivity, arthritis, lymphopenia, nephrotic syndrome and positive antinuclear antibodies. The patient was treated with oral corticosteroids and cyclophosphamide pulses for 2 years with clinical improvement and azathioprine was introduced as maintenance therapy. Later, she presented persistent thrombocytopenia and autoimmune hemolytic anemia refractory to higher dose of azathioprine $(150 \mathrm{mg} /$ day) and $20 \mathrm{mg} /$ day of prednisolone. Therapy with RTX $375 \mathrm{mg} / \mathrm{m}^{2}$ IV weekly for 4 weeks leads to an increase in platelet count reaching normal figure after 1 month. The patient has been followed up with no symptoms and with normal platelet count allowing discontinuation of azathio- prine and corticosteroid. She has been out of medication for 17 months.

Case 2 (SLE)

A 42-year-old female patient had 3-year past history of SLE characterized by articular symptoms, photosensitivity, thrombocytopenia, leukopenia and presence of antinuclear antibodies. She had been unsuccessfully treated for 3 years with corticosteroids (oral and pulses), azathioprine, intravenous immunoglobulin and danazol for refractory thrombocytopenia. Treatment with RTX was introduced, following the same protocol as described above, when platelet count reached $25,000 / \mathrm{mm}^{3}$. Thrombocytopenia responded well to RTX therapy; however, it recurred 9 months after initial therapy and a new course therapy is ongoing.

\section{Case 3 (RA)}

A 48-year-old female patient had 5-year past history of RA and secondary Sjögren's syndrome. Clinical features during evolution were symmetric poliarthritis of large and small joints, anemia, xerophtalmia, intermittent parotid gland enlargement, and positive rheumathoid factor and anticyclic citrullinated peptides (CCP) antibodies. She had been treated with methotrexate, leflunomide, cyclosporine, tacrolimus and sulphasalazine with no clinical improvement. After treatment with RTX, two doses of $1 \mathrm{~g}$ IV 2 weeks apart, with prednisone $1 \mathrm{mg} / \mathrm{kg}$ per day between doses, there was no clinical control of the disease albeit the patient exhibited rising levels of hemoglobin and lowering levels of erythrocyte sedimentation rate.

\section{Methods}

Blood samples

A 1-ml sample of peripheral blood was collected from each patient and normal healthy subject as control using ethylenediaminetetraacetic acid (EDTA). The patients were studied before and after rituximab therapy. Post-treatment evaluation was made after 6 weeks. After the collection, the whole peripheral blood (PB) was analyzed by flow cytometry. The study was approved by the Ethics Committee of our institution and all patients gave informed consent prior to the collection of blood.

Flow cytometry analysis of peripheral blood

Specific monoclonal antibodies (mAbs) were used with the following conjugated mouse anti-human mAbs in two- and three-color immunocytometric assays: FITC-conjugated 
mAbs anti-CD3 (HIT3a), PE-conjugated mAbs included anti-CD19 (HIB19), anti-CD25 (IL-2R $\alpha$ ) (M-A251) and anti-CD56 (B159), Cy-conjugated mAbs CD4 (RPA-T4) and PE-Cy5 anti-CD16 (3G8). Isotype-matched negativecontrol mouse IgG $_{1}$-FITC, PE or Cy (MOPC-21) mAbs. All mAbs were purchased from Becton-Dickinson (Mountain View, CA, USA).

White blood cell phenotyping was performed according to the manufacturers instructions with the following modifications. In $12 \times 75-\mathrm{mm}$ polystyrene tubes $50 \mu \mathrm{l}$ samples of peripheral blood, were added with $50 \mu \mathrm{l}$ of mix containing FACS buffer (HBSS, 10\% FCS, $0.01 \%$ sodium azide (Sigma-Aldrich), pH 7.2, $5 \mu$ l of each $\mathrm{mAb}$ ) and incubated for $30-45 \mathrm{~min}$ at $4^{\circ} \mathrm{C}$ in the dark. Following the incubation, erythrocytes were lysed using $2 \mathrm{ml}$ FACS lysing solution (BD Biosciences Pharmigen, San Diego, CA, USA.). The cells were washed twice in FACS buffer and resuspended in $200 \mu \mathrm{l}$ FACS buffer. The cells were immediately acquired with.30,000 events on the FACSort flow cytometer (BD Biosciences) and the data analyzed using CellQuest Software (BD Biosciences). The results are expressed as a percentage of positive cells within the selected gate. Distinct gate strategies were used to analyze major and minor lymphocytes subsets described as follows: lymphocytes were gated according to their FSC versus SSC dot plot characteristics. Gated lymphocytes were further analyzed for their immunophenotypic features on dual fluorescence dot plot distributions. Analysis of NK cell subsets was performed within $\mathrm{CD}^{-} \mathrm{CD}^{-} 6^{\mp} \mathrm{CD} 56^{+}$as previously described by Cooper et al. [17] and Vitelli-Avelar et al. [18]. Analysis of $\mathrm{CD}^{\text {dim }}$ (cytotoxic) and CD56 $6^{\text {bright }}$ (regulatory) NK cells was performed within $\mathrm{CD}^{-} \mathrm{CD}^{-} 6^{+} \mathrm{CD} 56^{+} \mathrm{NK}$ cell subsets. Analysis of $\mathrm{CD}^{2} 6^{\mathrm{dim}}$ and $\mathrm{CD} 56^{\text {bright }} \mathrm{NK}$ cells was performed within $\mathrm{CD}^{-}{ }^{-} \mathrm{CD} 16^{+} \mathrm{CD} 56^{+} \mathrm{NK}$ cell subsets. NKT cells were analyzed within $\mathrm{CD}^{+}$gated lymphocytes. B cells were analyzed within gated lymphocytes. Regulatory $\mathrm{T}$ cells $\left(\mathrm{CD} 4^{+} \mathrm{CD} 25^{\text {high }}\right)$ were analyzed within gated $\mathrm{CD} 4^{+}$ $\mathrm{T}$ cells.

\section{Results}

Depletion of B cell $\left(\mathrm{CD} 19^{+}\right)$occurred in all three patients SLE and RA treated with RTX, 6 weeks after treatment (Fig. 1a). A slight increase in the percentage of circulating $\mathrm{T}\left(\mathrm{CD}^{+}\right)$cells in all patients after RTX treatment were observed (Fig. 1b) while only a small rise in $\mathrm{T} \mathrm{CD}^{+}$cells in SLE2 patient was detected (Fig. 1c). A higher population of circulating regulatory $\mathrm{CD} 4^{+} \mathrm{CD} 25^{\text {high }} \mathrm{T}$ cells in all treated patients was noted (Fig. 1d), and comparison between Fig. 1c, d indicates that the raised regulatory $\mathrm{T}$ cell population could not be attributed to a higher frequency of total $\mathrm{T} \mathrm{CD} 4^{+}$cell count after treatment.

The frequency of the total $\mathrm{NK}$ cells $\left(\mathrm{CD}^{-}{ }^{-} \mathrm{CD} 56^{+}\right.$, were lower in patients either before or after treatment in comparison to controls (Fig. 2a). The patient with sustained clini-
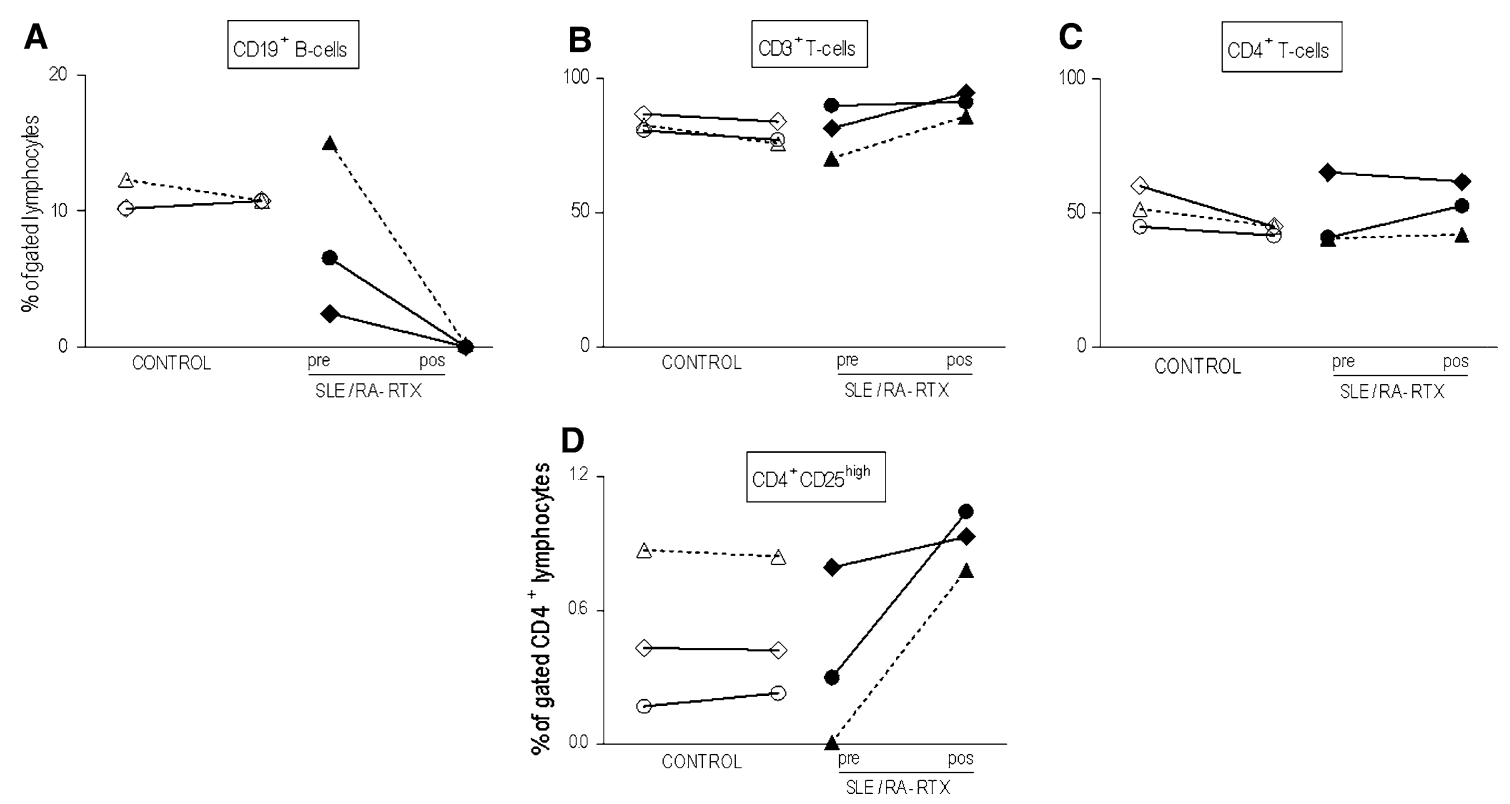

Fig. 1 Analysis of total lymphocytes T and B cell subsets and regulatory $\mathrm{CD} 4{ }^{+} \mathrm{CD} 25^{\text {high }} \mathrm{T}$ cell present in peripheral blood of patients with systemic lupus erythematosus (SLE) and rheumatoid arthritis (RA) before and after treatment with rituximab (SLE/RA-RTX). SLE1 (filled square), SLE2 (filled circle), (RA3) (filled triangle) and controls on left (open symbols). Lymphocyte phenotypic analysis was performed using a triple-labelling protocol: anti-CD3 FITC anti-CD19 PE or antiCD4 Cy to identify a total B cells $\left(\mathrm{CD} 19^{+}\right), \mathbf{b}$ total T cells $\left(\mathrm{CD}^{+}\right),(\mathrm{C})$ $\mathrm{T}$ cell subset $\left(\mathrm{CD}^{+}\right)$analyzed within gated lymphocytes. Double staining with anti-CD4 Cy and anti-CD25 PE, was used to identify regulatory $\mathrm{CD} 4^{+} \mathrm{CD} 25^{\text {high }} \mathrm{T}$ cells (D) within gated $\mathrm{CD} 4^{+} \mathrm{T}$ cells 
Fig. 2 Analysis of total natural killer (NK) cell and subsets present in peripheral blood of patients with systemic lupus erythematosus (SLE) and rheumatoid arthritis (RA) before and after treatment with rituximab (SLE/RA-RTX). SLE1 (filled square), SLE2 (filled circle), (RA3) (filled triangle) and controls on left (open symbols). Phenotypic studies were performed using a triple-labelling protocol anti-CD3 FITC, anti-CD56 PE and anti-CD16 PE-Cy5 to identify a total NK cells

$\mathrm{CD}^{-}{ }^{-} \mathrm{CD} 16^{\mp} \mathrm{CD} 56^{\mp}, \mathbf{b}, \mathbf{d}$

$\mathrm{CD} 3^{-} \mathrm{CD} 16^{+} \mathrm{CD} 56^{\mathrm{dim}}$ cells and

CD3 ${ }^{-} \mathrm{CD} 16^{-} \mathrm{CD}^{-\mathrm{dim}}$ cells, $\mathbf{c}, \mathbf{e}$

$\mathrm{CD}^{-} \mathrm{CD} 16^{+} \mathrm{CD} 56^{\text {bright }}$ cells and CD $3^{-} \mathrm{CD} 16^{-} \mathrm{CD} 56^{\text {bright }}$ cells.

The results of total NK cells were calculated within gated lymphocytes and its subsets within NK cells
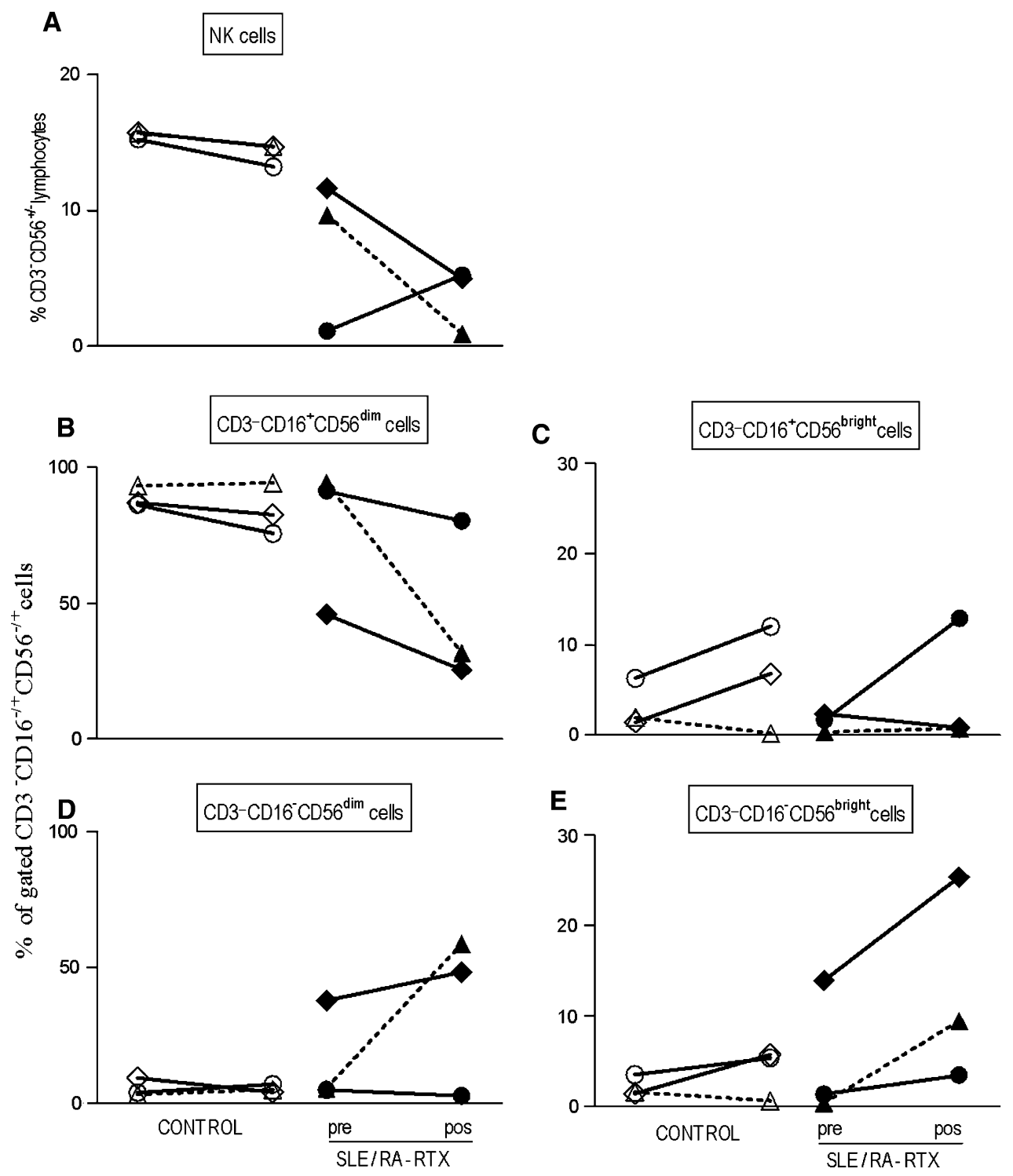

cal response (SLE1) had a dramatic drop in circulating NK cells, as well as the RA patient (Fig. 2a). A decreased population of circulating $\mathrm{CD}^{-} \mathrm{CD}^{-} 6^{+} \mathrm{CD} 56^{\mathrm{dim}} \mathrm{NK}$ cell subset was detected in all RTX treated patients (Fig. 2b). An increase of $\mathrm{CD}^{-}{ }^{-} \mathrm{CD} 16^{+} \mathrm{CD} 56^{\text {bright }}$ cells was noted in SLE2 patients, but this variation was close to that observed in control untreated subjects (Fig. 3c) while the increase of $\mathrm{CD}^{-}{ }^{-} \mathrm{CD} 16^{-} \mathrm{CD}^{\mathrm{dim}}{ }^{\mathrm{dim}}$ in the unresponsive RA patient was out of the range of differences observed among controls (Fig. 2d). Strikingly, all patients increased percentage of $\mathrm{CD}^{-}{ }^{-} \mathrm{CD} 16^{-} \mathrm{CD}^{2} 6^{\text {bright }}$ in comparison to controls (Fig. 2e).

NKT cells and their subsets gave more variable results. The results of total $\mathrm{NKT}\left(\mathrm{CD}^{+} \mathrm{CD}^{+} 6^{+}\right)$are illustrated in Fig. 3A. NKT cells analysis was classified into NKT1, $\mathrm{CD}^{+}{ }^{+} \mathrm{CD}_{16}{ }^{+} \mathrm{CD}_{56}{ }^{-}$(Fig. 3b), NKT2, CD ${ }^{+} \mathrm{CD} 16^{-} \mathrm{CD}^{-} 6^{+}$ (Fig. 3c) and NKT3 $\mathrm{CD}^{+} \mathrm{CD} 16^{+} \mathrm{CD} 56^{+}$(Fig. 3d). The most consistent observation was a reduction of all NKT subsets in the patient with sustained clinical response (Fig. 3b, c, d) albeit a relative percentage of NKT cells was raised in this patient (Fig. 3a). The SLE2 patient showed a notable rise in circulating NKT3 cells (Fig. 3d).

\section{Discussion}

As expected, RTX promoted depletion of circulating B cell $\left(\mathrm{CD} 19^{+}\right)$in all three patients. In both SLE patients who experienced clinical remission of severe thrombocytopenia and RA patient with no clinical response, the expression of $\mathrm{CD} 19^{+} \mathrm{B}$ cells in peripheral leukocytes was undetectable 6 weeks after treatment (Fig. 1a). Although some authors observed a direct relationship between decreased CD $19^{+} \mathrm{B}$ cell and clinical improvement in SLE [2, 19], not all medical literature on RTX therapy supports this concept [1] 


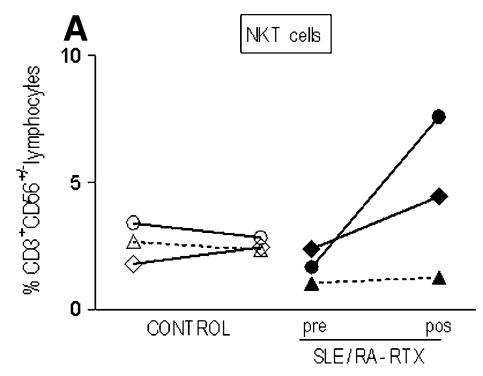

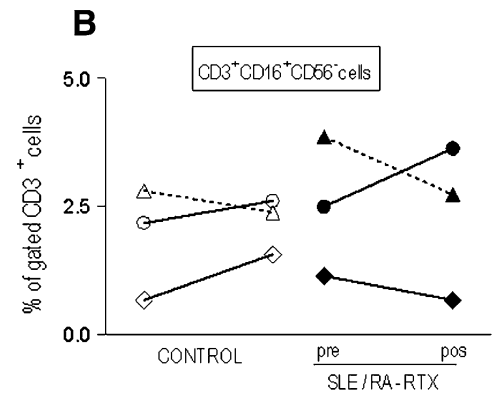

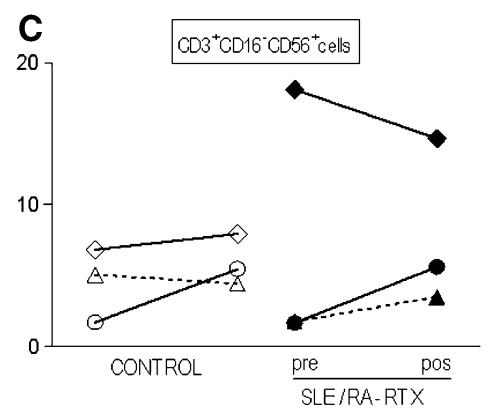

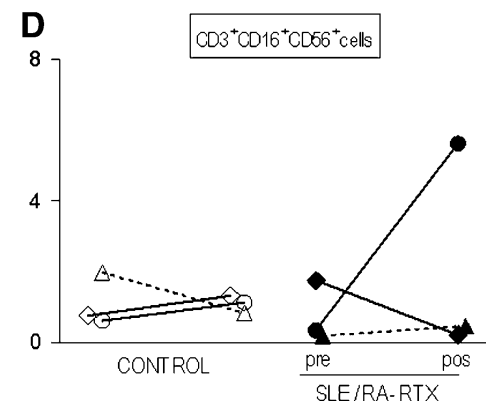

Fig. 3 Analysis of total natural killer T (NKT) cells and subsets present in peripheral blood of patients with systemic lupus erythematosus (SLE) and rheumatoid arthritis (RA) before and after treatment with rituximab (SLE/RA-RTX). SLE1 (filled square), SLE2 (filled circle), (RA3) (filled triangle) and controls on left (open symbols). NKT phe- notypic analysis was performed using a triple-labelling protocol antiCD3 FITC, anti-CD56 PE and anti-CD16 PE-Cy5 to identify a total NKT cells $\left(\mathrm{CD}^{+} \mathrm{CD} 16^{\mp} \mathrm{CD}^{ \pm} 6^{ \pm}\right)$, b NKT1 cells $\left(\mathrm{CD} 3^{+} \mathrm{CD} 16^{+} \mathrm{CD} 56^{-} /\right.$ $\left.\mathrm{CD}^{+}\right)$, $\mathbf{c}$ NKT2 cells $\left(\mathrm{CD}^{+} \mathrm{CD} 16^{-} \mathrm{CD} 56^{+} / \mathrm{CD}^{+}\right)$and $\mathbf{d} \mathrm{NKT} 3$ cells $\left(\mathrm{CD}^{+} \mathrm{CD}^{+} 6^{+} \mathrm{CD} 6^{+} \mathrm{CD}^{+}\right)$analyzed within gated $\mathrm{CD}^{+}$lymphocytes suggesting that other not evaluated immune factors may be involved. Indeed, although the B cells depletion occurred after RTX therapy in all three patients of the present study, the clinical response was variable. Both SLE patients present severe thrombocytopenia as the major clinical complication, a situation in which autoantibodies are clearly pathogenic [20].

In this study, we investigated NK cells subsets based on the cell surface of NK cells expressing lower level of CD56 $\left(\mathrm{CD} 56^{\mathrm{dim}} \mathrm{CD} 16^{+}\right)$, known as a more cytotoxic subset, whereas NK cells $\left(\mathrm{CD} 56^{\text {bright }} \mathrm{CD} 16^{\mp}\right)$ are involved in the regulation, based on the observation that $\mathrm{CD} 56^{\text {bright }}$ subset is the major source of IFN- $\gamma$ cytokines [21]. RTX and other anti-CD20 monoclonal antibodies are known to promote downregulation of $\mathrm{CD} 16$, which is the $\mathrm{IgG}$ receptor they use to mediate their effector functions [22]. Therefore, it was important to verify NK cells subsets according to CD16 expression (Fig. 2). All patients had a relative lower population of circulating NK cells when compared to control subjects. The patient with sustained clinical response had a notable decrease of total NK cell population in peripheral blood, but so did the patient with non responsive RA (Fig. 2a). The most striking observation was the rise in circulating $\mathrm{CD}^{\text {bright }} \mathrm{CD}^{\text {b6 }}{ }^{-}$(regulatory NK cells) in the patient with sustained clinical response. More importantly, this elevation occurred in that patient who had higher baseline population of circulating regulatory NK cells. This observation encourages future works focusing on evalua- tion of regulatory NK cells as a prognostic factor that may predict clinical response after RTX therapy [that could be obtained as early as 6 months (weeks) after initiation of treatment]. In addition, baseline circulating regulatory $\mathrm{NK}$ cells must also be explored as a predictor of clinical response. In Fig. 2, we also show that all patients experienced a decrease in $\mathrm{CD}^{-}{ }^{-} \mathrm{CD} 16^{+} \mathrm{CD} 56^{\mathrm{dim}}$ cells (Fig. 2b) and a rise in $\mathrm{CD}^{-}{ }^{-} \mathrm{CD} 16^{-} \mathrm{CD} 56^{\text {bright }}$ (Fig. 2e). Although these data may suggest a switch from more cytotoxic population to regulatory NK cells, it should be highlighted that such changes may be partially or entirely explained by the downregulation of CD16 promoted by anti-CD20 therapies [22].

NKT cells were further characterized accordingly to the previous reported classification by Vitelli-Avelar and colleagues [18]: NKT1 cells $\left(\mathrm{CD}^{+} \mathrm{CD}^{+} 6^{+} \mathrm{CD}^{2} 6^{-}\right)$, NKT2 cells $\left(\mathrm{CD}^{+} \mathrm{CD}^{-} 6^{-} \mathrm{CD} 56^{+}\right)$and $\mathrm{NKT} 3$ cells $\left(\mathrm{CD} 3^{+} \mathrm{CD} 16^{+}\right.$ $\mathrm{CD}^{2} 6^{+}$). They characterized subpopulations of circulating NKT cells observing increased values of NKT2 (CD3 ${ }^{+}$ $\mathrm{CD}_{16}{ }^{-} \mathrm{CD} 6^{+}$) cells in indeterminate forms of Chagas disease thus suggesting a potential role of these cells in immunomodulation that may prevent progression to chronic cardiac disease. In the present study, no specific change in NKT subsets could be associated with successful treatment (Fig. 3b-d). An increasing population of circulating NKT3 subset outside the range of variation among controls and other patients was observed in patient SLE2. Curiously, in the SLE with sustained response to RTX, 
there was a relative decrease in all NKT cells subsets. Thus, it is not known how NKT subsets have coordinated functions and how a decrease in one NKT cell subset can be compensated by other cells maintaining the same physiological effects.

Our results for regulatory $\mathrm{CD} 4^{+} \mathrm{CD} 25^{\text {high }} \mathrm{T}$ cells mirror those of Bonelli and colleagues [23] as we could observe a trend for increasing of this subset after RTX treatment. Increased frequency of regulatory $\mathrm{CD} 4{ }^{+} \mathrm{CD} 25^{\text {high }} \mathrm{T}$ cells, however, could not predict clinical outcome since it was observed in patients with clinical improvement and in the patient with refractory RA (Fig. 1d). We were not able to perform FoxP3 analyses in the present study. The transcriptional factor Foxp3 has been used as a better marker of these cells. However, in SLE, disease activity has been found to be inversely correlated better with $\mathrm{CD} 4{ }^{+} \mathrm{CD} 25^{\text {high }}$ $\mathrm{T}$ cells than Foxp3 expressing CD4 ${ }^{+} \mathrm{T}$ cells. There is a dissociation between $\mathrm{CD} 4^{+} \mathrm{CD} 25^{\text {high }} \mathrm{T}$ cells and FoxP3 expression and, in SLE, FoxP3 may be found in $\mathrm{CD} 4^{+} \mathrm{T}$ cells with low or intermediate expression of CD25 suggesting it may be at least in part a marker of $\mathrm{T}$ cell activation [23]. In contrast, FoxP3 has been suggested by other recent papers to be a strong biomarker of response after RTX therapy [7, 24].

Overall, our results indicate that measurement of circulating B and T lymphocytes, NK and NKT cells subsets, are subject to considerable variations after RTX therapy. It is not currently known to which extent such changes can be attributed to direct effects of B cell drop or as secondary compensatory mechanism. For instance, macrophage phenotypical changes after RTX infusion are interpreted as a compensatory response to loss of APC function of B cells [9], while reduced markers of $\mathrm{T}$ cell activation are considered a direct response of B cell drop and loss of a source of antigen presentation and cytokines production [3, 8]. Future works on the role of regulatory NK and NKT cells subsets after RTX therapy should have special focus on the association between regulatory CD56 ${ }^{\text {bright }} \mathrm{NK}$ cell subset and decreased of NKT cell subsets with sustained clinical response.

Acknowledgments This work was supported by Grant 304713/ 2002-3 (M.G.R) by Conselho Nacional de Desenvolvimento Científico e Tecnológico $(\mathrm{CNPq})$. M.S. is currently receiving a scholarship from Conselho Nacional de Desenvolvimento Científico e Tecnológico (CNPq).

Conflict of interest statement The authors have no conflict of interest.

\section{References}

1. Stohl W, Looney RJ (2006) B cell depletion therapy in systemic rheumatic diseases: different strokes for different folks? Clin Immunol 121:1-12. doi:10.1016/j.clim.2006.03.010
2. Strand V, Kimberly R, Isaacs JD (2007) Biologic therapies in rheumatology: lessons learned, future directions. Nat Rev Drug Discov 6:75-92. doi:10.1038/nrd2196

3. Sfikakis PP, Boletis JN, Lionaki S et al (2005) Remission of proliferative lupus nephritis following B cell depletion therapy is preceded by down-regulation of the $\mathrm{T}$ cell costimulatory molecule CD40 ligand: an open-label trial. Arthritis Rheum 52:501-513. doi:10.1002/art.20858

4. Tanaka Y, Yamamoto K, Takeuchi T et al (2007) A multicenter phase I/II trial of rituximab for refractory systemic lupus erythematosus. Mod Rheumatol 17:191-197. doi:10.1007/s10165-007$0565-\mathrm{Z}$

5. Kavanaugh A, Rosengren S, Lee SJ et al (2007) Assessment of rituximab's immunomodulatory synovial effects (the ARISE trial). I: clinical and synovial biomarker results. Ann Rheum Dis 67:402428. doi:10.1136/ard.2007.074229

6. Smolen JS, Keystone EC, Emery P et al (2007) Consensus statement on the use of rituximab in patients with rheumatoid arthritis. Ann Rheum Dis 66:143-150. doi:10.1136/ard.2006.061002

7. Browning JL (2006) B cells move to centre stage: novel opportunities for autoimmune disease treatment. Nat Rev Drug Discov 5:564-576. doi: $10.1038 / \mathrm{nrd} 2085$

8. Sfikakis PP, Souliotis VL, Fragiadaki KG et al (2007) Increased expression of the FoxP3 functional marker of regulatory $\mathrm{T}$ cells following B cell depletion with rituximab in patients with lupus nephritis. Clin Immunol 123:66-73. doi:10.1016/j.clim.2006. 12.006

9. Toubi E, Kessel A, Slobodin G et al (2007) Changes in macrophage function after rituximab treatment in patients with rheumatoid arthritis. Ann Rheum Dis 66:818-820. doi:10.1136/ard.2006.062505

10. Shi FD, Van Kaer F (2006) Reciprocal regulation between natural killer cells and autoreactive T cells. Nat Rev Immunol 6:751-760. doi:10.1038/nri1935

11. Miyake S, Yamamura T (2007) NKT cells and autoimmune diseases: unraveling the complexity. Curr Top Microbiol Immunol 314:251-267. doi:10.1007/978-3-540-69511-0_10

12. Green MR, Kennell AS, Larche MJ et al (2005) Natural killer cell activity in families of patients with systemic lupus erythematosus: demonstration of a killing defect in patients. Clin Exp Immunol 141:165-173. doi:10.1111/j.1365-2249.2005.02822.x

13. Green MR, Kennell AS, Larche MJ et al (2007) Natural killer T cells in families of patients with systemic lupus erythematosus: their possible role in regulation of IGG production. Arthritis Rheum 56:303-310. doi:10.1002/art.22326

14. Shevach EM, Piccirillo CA, Thornton AM et al. (2003) Control of $\mathrm{T}$ cell activation by $\mathrm{CD} 4+\mathrm{CD} 25+$ suppressor $\mathrm{T}$ cells. Novartis Found Symp 252:24-36, discussion 36-44, 106-114

15. Barath S, Aleksza M, Tarr T et al (2007) Measurement of natural (CD4+CD25high) and inducible (CD4+IL-10+) regulatory T cells in patients with systemic lupus erythematosus. Lupus 16:489-496. doi: $10.1177 / 0961203307080226$

16. Crispin JC, Martinez A, Alcocer-Varela J (2003) Quantification of regulatory $\mathrm{T}$ cells in patients with systemic lupus erythematosus. J Autoimmun 21:273-276. doi:10.1016/S0896-8411(03)00121-5

17. Cooper MA, Fehniger TA, Caligiuri MA (2001) The biology of human natural killer-cell subsets. Trends Immunol 22:633-640. doi:10.1016/S1471-4906(01)02060-9

18. Vitelli-Avelar DM, Sathler-Avelar R, Dias JC et al (2005) Chagasic patients with indeterminate clinical form of the disease have high frequencies of circulating CD3+CD16-CD56+ natural killer $\mathrm{T}$ cells and CD4+CD25High regulatory T lymphocytes. Scand J Immunol 62:297-308. doi:10.1111/j.1365-3083.2005.01668.x

19. Jonsdottir T, Gunnarsson I, Risselada A et al (2007) Treatment of refractory SLE with rituximab plus cyclophosphamide: clinical effects, serological changes, and predictors of response. Ann Rheum Dis 56:1263-1272 
20. McMillan R (2007) The pathogenesis of chronic immune thrombocytopenic purpura. Semin Hematol 44:S3-S11. doi:10.1053/ j.seminhematol.2007.11.002

21. Moretta A, Bottino C, Mingari MC et al (2002) What is a natural killer cell? Nat Immunol 3:6-8. doi:10.1038/ni0102-6

22. Bowles JA, Wang SY, Link BK et al (2006) Anti-CD20 monoclonal antibody with enhanced affinity for CD16 activates NK cells at lower concentrations and more effectively than rituximab. Blood 108:2648-2654. doi:10.1182/blood-2006-04-020057
23. Bonelli M, von Dalwigk K, Savitskaya A et al (2008) Foxp3 expression in CD4+ T cells of patients with systemic lupus erythematosus (SLE): a comparative phenotypic analysis. Ann Rheum Dis 67:664-671. doi:10.1136/ard.2007.074690

24. Vallerskog T, Gunnarsson I, Widhe M et al (2007) Treatment with rituximab affects both the cellular and the humoral arm of the immune system in patients with SLE. Clin Immunol 122:62-74. doi:10.1016/j.clim.2006.08.016 